Portland State University

PDXScholar

6-16-2021

\title{
Scratch a Desert, Produce a Garden: The American Failure to Facilitate a Two-State Solution
}

Sophie Myers Concannon

Portland State University

Follow this and additional works at: https://pdxscholar.library.pdx.edu/honorstheses

Part of the International Relations Commons

Let us know how access to this document benefits you.

\section{Recommended Citation}

Concannon, Sophie Myers, "Scratch a Desert, Produce a Garden: The American Failure to Facilitate a TwoState Solution" (2021). University Honors Theses. Paper 1061.

https://doi.org/10.15760/honors.1087

This Thesis is brought to you for free and open access. It has been accepted for inclusion in University Honors Theses by an authorized administrator of PDXScholar. Please contact us if we can make this document more accessible: pdxscholar@pdx.edu. 
Scratch a Desert, Produce a Garden:

The American Failure to Facilitate a Two-State Solution

by

Sophie Myers Concannon

An undergraduate honors thesis submitted in partial fulfillment of the requirements for the degree of

Bachelor of Arts

in

University Honors

and

Political Science

Thesis Adviser

Dr. Lindsay Benstead

Portland State University

May 2021 


\section{Table of Contents}

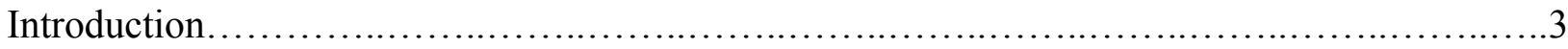

A. The American-Israeli Parallel Narrative........................................................4

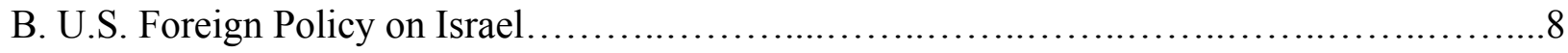

i. Middle East Peace Plan........................................................... 11

C. Changing Tides: Public Support for a Two-State Solution.................................13

ii. The Two-Party Split............................................................ 19

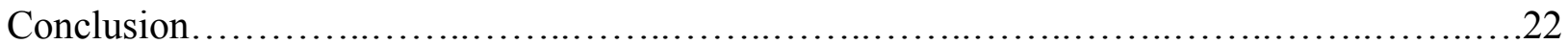

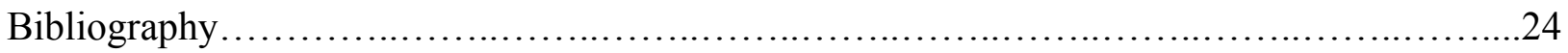




\section{Introduction}

According to Gallup polls from February 2020, 55\% of Americans supported Palestinian statehood - the first time in eight years a majority supported the concept of an independent Palestinian state. While support decreased marginally by 3 points as of February 2021, the majority still holds with the percentage of Americans supporting an independent Palestine at $52 \%$. This increase and subsequent maintenance of majority support marks a distinct shift in American public opinion of Israel, which has historically prioritized the U.S.-Israel relationship over the facilitation of a two-state solution with an independent Palestine. This shift is likely reflective of a variety of complex factors, including contradictory but public-facing two-state solution messaging from the Trump administration via the Middle East peace plan, as well as increased sympathy for the Palestinian cause and distrust in U.S. foreign policy objectives, as scholars such as Malka and Rynhold have argued. This new data also brings up an interesting contradiction; even though the majority of Americans now support a two-state solution, this change is not reflected in foreign policy, Congress members' policy positions, or the official Democratic and Republican party platforms, which use verbiage such as "unequivocal" and "ironclad" to describe their commitment in continuing to give military and foreign aid to Israel (Congressional Research Service, 2020).

In this paper, I explore why the United States hasn't retooled its foreign policy objectives and practice to represent the desire of its constituents, while consistently increasing aid to Israel, supporting illegal land seizure, and consistently failing to facilitate attempts of statehood to Palestine. I also investigate why American politicians fail to represent the interests of their constituent bases when those bases do not unequivocally support Israel at the expense of a Palestinian state. To answer these pressing questions, I'll examine three factors: first, the 
pervasive created narrative that joins Israeli and American interests, summed up succinctly by former President Richard Nixon: “Americans admire a people who can scratch a desert and produce a garden. The Israelis have shown qualities that Americans identify with: guts, patriotism, idealism, a passion for freedom” (Nixon Foundation). Second, I'll address the disparity between American foreign policy on the issue of a two-state solution versus public opinion, represented through military aid, strategic imperatives and the aforementioned parallel narrative. Finally, I'll address this monumental, unprecedented shift in public opinion toward the facilitation of a two-state solution with support for an independent Palestine, and the failure of Congress to reflect. By examining these factors, I hope to determine why there's such a large gap between what Americans want and what is put into action on the issue of a two-state solution.

\section{A. The American-Israeli Parallel Narrative}

In order to explain the "six decades of public affection" (Cavari) between the United States and Israel that has fueled everything from public opinion to foreign policy, the nature of the deep ties between the two states first has to be explored. According to Haim Malka in Crossroads: the Future of the U.S.-Israel Strategic Partnership, the foundation of the U.S.-Israel alliance is two-fold: first, that the U.S. and Israel "share an exceptionally deep and abiding commitment to the values of a Western-style democratic society" and second, the two states share a "common strategic outlook" based on a shared understanding of the complexities of the region (18). The latter has been validated many times over by strategic political alliances and defense funding, reinforced according to Malka by the Cold War and more recently, the events of September 11, creating a common enemy and common goals on a global front. To the first point, however, Malka argues the original recognition of Israel by Truman in 1948 was not a strategic 
decision; rather, it was based on Truman's personal religious convictions and "sense of moral obligation toward a persecuted minority" (3). Not only that, Malka argues Truman based his decision on the "abstract notion that Israelis and Americans shared basic beliefs rooted in liberty, democracy, and Judeo-Christian values" (48). Malka's further description of immediate American support for the establishment of a new nation in the region based on principles of religious freedom and determination is telling:

"Early U.S. support for Israel was also built on the idea of a small democracy struggling for survival against the odds, all while trying to absorb hundreds of thousands of immigrants. Many Americans glimpsed themselves and the American pioneer spirit in Israel's struggle for independence and survival. Israeli interlocutors tended to speak English well, were highly educated, and espoused a commitment to Western liberal and democratic ideals." (3)

According to Amy Kaplan's Our American Israel: The Story of an Entangled Alliance, this parallel narrative was strengthened not just by diplomatic strategy and state-making, but also by American media. Through movies, television, films and, importantly, through sermons, the U.S. public identified Zionist settlers in Palestine as kin to American pioneers in the 18th century. Worth mentioning, also, is Kaplan's emphasis on the "subduing of indigenous peoples" as a common narrative thread (51). This evolved in later decades with the advent of the Six-Day War, which established Israel's military might and further endeared the American people to a story of "the good fight." 
This perception of Israel as an exceptional state striving against the odds is a direct reflection of the American perception of exceptionalism that defines the country's self-image. It makes sense, then, that Americans latched on to a narrative about an exceptional state prevailing despite religious persecution. It's important to note that this does not align with narrative that Israel perpetuates: according to Paul Scham, Benjamin Pogrund et al. in "Introduction to Shared Narratives-A Palestinian-Israeli Dialogue," the familiar Israeli narrative "demonstrates a justified 'return' of those dispossessed many generations before" (2). The U.S. narrative, then, is at least partially an American creation. It focuses not on return and birthright, but rather on self-determination and freedom, tying the characteristics of American independence with those of Israel. Similarly, nor is the bastion of democracy in the Middle East referenced so frequently in scholarship that Israel has been painted to be a completely accurate image: like Malka describes, this characterization is "convenient...but it has denied those parts of Israel's social and national makeup that espouse an esatern Mediterranean and religious culture rather than a Western liberal ethos" (45). Malka argues that this fundamental cultural difference has been largely erased in order to facilitate a one-to-one parallel narrative between the two states, despite Israel's own narrative of events, which prioritize specific ordained religious rights and prior land ownership.

Similarly, in "The United States and Israel: The Risk of Growing Apart," Mark Heller argues the perception of a narrative convergence between Israel and the United States has facilitated a broadly receptive environment for a message of commonality between the two states. Absent that environment, Heller argues it's doubtful that pro-Israeli activism or any such social cause could have produced the outcomes "characterizing American policy over the past half-century" (3). Heller also argues if that receptive environment changes because of societal 
force or political culture in either or both countries, challenging this narrative overlap, it could significantly weaken the bonds between the two states (8). This narrative convergence between Israel and the United States for the past six decades has served to facilitate overwhelming public support, in order to ensure the safety and strength of the U.S.-Israel relationship.

Another upstanding pillar of the overwhelming public support for the past six decades prior to 2020 is that America's interests have never significantly diverged from Israel's, because Israeli hegemony in the Middle East is so closely tied to America's goals both as an individual state and in foreign relations, a theory backed by Heller (5). Heller argues the U.S. provides a "political shield" for Israel against international criticism or punishments and in return, the U.S. has a political ally to help broker disputes in the region with Egypt and Jordan, as well as new technologies and counter-terrorism strategies gleaned from Israel (2). These points of convergence bringing the two states together helps justify support for maintaining tremendous amounts of military support and aid, as will be elaborated upon later. Concurrently, Malka argues a strategic alliance was formed with Israel as a tool during the Cold War, and continued to be a tool in the Middle East region for American strategic interests. America has largely forgotten how the interweaving of Israel and American interests occurred, but this evolving narrative is critical to the contemporary relationship. The alliance between Israel and America, which Malka says is built on "shared political and religious values," extends deeper than any other American foreign interest (45). He states the following:

"An alliance of this unique nature rests on perceptions of shared political and religious values; on enduring historical memory of unspeakable brutality toward millions of Jews; on a common commitment to democracy, rule of law, and human rights; on the 
perception of common threats; on largely compatible, if not fully agreed, strategic doctrine; and on a web of Jewish family ties that span the oceans, all given protracted endurance by widespread American public admiration for Israel that stretches well beyond American Jewry and is expressed repeatedly by the U.S. Congress." (Malka 9)

This narrative convergence created primarily by America is the background to understanding why American foreign policy in Israel, as well as party and congressional platforms supposedly representative of constituent demands, do not follow public opinion. Public opinion now supports diverging from the patterns of aid and support the U.S. government has consistently given to Israel. American constituents now would also see an independent Palestinian state realized alongside an Israeli state, something that would threaten Israeli hegemony and objectively weaken U.S.-Israel relations. The failure of the government to constructively or materially recognize or facilitate these aims is explained through the shared narrative created by America and presented to the public, but is further justified through foreign policy.

\section{B. U.S. Foreign Policy on Israel}

Support of a two-state solution requires the support of an independent Arab Palestine. The United States was the first country to recognize the independence of a Jewish state in 1948. However, according to scholar Rashid Khalidi, "yet to support in deed (as opposed to word) the independence" of Arab Palestine" (21). This is supported by the pattern of investments in the region the U.S. has exhibited since the establishment of the Israeli state, as well as the failure to facilitate the creation of an independent Palestinian state. 
Since 1948, the United States has provided Israel with approximately \$148 billion in aid not adjusted for inflation, a majority of the sum categorized as military aid (CRS 2020). This figure does not include the FY2019-FY2028 MOU drafted in 2018 pledging \$38 billion in military aid. According to the same data, Israel is the largest cumulative recipient of U.S. aid since World War II. Weapons programs such as Iron Dome, David's Sling, Arrow ballistic missile programs and more have received a consistent increase in funding over time. The fact that this aid is primarily military is by design; in order to facilitate the "QME" or "Qualitative Military Edge" strategy for Israel, funds go to equipment, training, arms sales, and technology. MOUs, or Memoranda of Understanding(s), were instituted in 1999 as the primary form of providing military aid, and don't require Senate ratification.

In 2002, Stephen Zunes argued under the Institute of Policy Studies that the "stronger and more willing to cooperate with U.S. interests that Israel becomes, the stronger the support" (Institute for Policy Studies). Zunes cites U.S. aid increasing by $450 \%$ after the 1967 war, partly due to Israel's willingness to provide new Soviet weapons to the U.S. government. The U.S. increased financial support again in 1971, 1973, 1979 and 1982 after strategic victories by Israel. The United States allocated $\$ 1.5$ billion in economic aid to Israel after signing an agreement for strategic cooperation and joint military exercises. In 2012, scholars suggested facilitating a two-state solution, if the U.S. fails to "reinforce...commitment to initiating and carrying out peace negotiations," using diplomatic and economic levers to "pressure Israel" should be considered (Woodrow Wilson School of Public and International Affairs).

However, not even internal pressure seems to affect how the U.S. determines aid to Israel. Generally, bills involving reduced support have died in committees or otherwise failed to reach 
the floor. H.R. 4391 introduced in 2017 aimed to "prohibit U.S. assistance to Israel from being used to support the military detention, interrogation, or ill-treatment of Palestinian children in violation of international humanitarian law," and died in the Foreign Affairs Committee. An amended version from 2019, H.R. 2407, aimed to authorize "\$19 million to independent organizations to monitor possible human rights violations," was also referred to the Foreign Affairs Committee and further action has yet to be taken. Such attempts to moderate and place restrictions on military aid to Israel, or even impose conditional boundaries, have never succeeded. Threats of pursuing "legislation that conditions the $\$ 3.8$ billion in military funding [of FY2020]" were issued by 12 House members and one Senator during Israeli Prime Minister Benjamin Netanyahu's 2020 consideration of annexation of further territory, never proceeding beyond a letter. Bills which offer increased funding — either military or economic — such as H.R. 7617, which passed the House in 2020 and will provide $\$ 500$ million for joint missile defense cooperation split between the programs listed above, pass without amendments or other stipulations (CRS 2018).

Conversely, "bilateral assistance" to the Palestinians since 1994 has totaled approximately \$5 billion, not including U.S. contributions to humanitarian aid (CRS 2018). Bilateral assistance to Israel since 1994 totals approximately $\$ 89$ billion, not including economic or missile defense aid. In 2017-18, President Donald Trump cut \$231 million in economic assistance "intended for the West Bank and Gaza (including \$25 million for East Jerusalem hospitals)" (Nauert 2018), halting all FY2017 aid to Palestine. In 2018, Trump also halted all aid to the United Nations Relief and Works Agency (UNRWA) for FY2019, a move widely criticized by both the international community and members of the U.S. Congress (Schiff 2018). Similarly, in 2018, Congress enacted stricter restrictions for Economic Support Fund (ESF) aid under the 
Taylor Force Act, theoretically suspending all aid that benefits the PA under a series of complex restrictions surrounding alleged terrorism and terrorist activities, which are ill-defined (CRS 2018). This failure to commit to humanitarian aid toward Palestine while increasing primarily military aid to Israel indicates a dedication to the U.S.-Israeli relationship that supersedes the dedication to the facilitation to a two-state solution, let alone an independent Palestine.

\section{i. Middle East Peace Plan. 2020-Future}

The actions of former President Donald Trump and his administration, especially regarding the controversial Middle East Peace Plan enacted in 2020, represents a paradox that has influenced the tide of public support for a Palestinian state in a seemingly contradictory way. It is inarguable that the Trump administration's actions have been largely pro-Israel, faciliatating further Israeli dominance in West Bank regions. For example, as in May 2020, U.S. Secretary of State Mike Pompeo said on whether to annex parts of the West Bank that it was an "Israeli decision" (Reuters). Trump also recognized Jerusalem as Israel's capital and relocated the American embassy to Jerusalem, despite vehement opposition by Democrats (The New York Times). Conversely to the increasing aid toward Israel over time, in 2018, the Trump administration significantly cut funding for Palestine after PLO and PA officials cut off diplomatic contact with the United States after the 2017 decision to recognize Jerusalem as the Israeli capital, according to data from the Congressional Research Service.

However, the peace plan may not have increased polarization regarding the Israeli-Palestinian issue; in fact, circumstantial evidence suggests that Trump's outward-facing support of a two-state solution has increased sympathy toward the eventual goal of an independent Palestine from right-leaning Americans, despite the actual text of the plan serving to 
further Israeli supremacy over contested land and the prioritizing of the U.S.-Israel relationship. While it cannot be definitively said that Trump's actions furthered sympathy for an independent Palestinian state without extensive research, this public-facing support of a two-state solution may have softened the vehemently pro-Israel stance of the polarized Republican right.

From 2018 to 2019, the percentage of Republicans who said they sympathized more with Israel dropped 11 points, from the all-time high of $87 \%$ to $76 \%$ (Gallup). Contextually, the $87 \%$ figure was also taken around the time the Trump administration planned to move the U.S. embassy to Jerusalem, a generally well-received decision by Republicans and pro-Israel factions. From 2017 to 2020, Republican support for an independent Palestinian state rose 19 points, from $25 \%$ to $44 \%$ (Gallup). From 2019 to 2020 alone, it rose 11 points, indicating circumstantially that the Middle East Peace Plan may have influenced the Republican perception of the feasibility or necessity of facilitating a two-state solution.

Trump's actions may have also spurred further sympathy for what Rynhold calls the "Palestinian plight," though indirectly. Rynhold found that between 2014 and 2017, the sharp rise in acknowledgement of racism in the United States among Democrats correlates with the rise in sympathy for Palestinians and the Palestinian cause (54). An article published in The Washington Post entitled "The Growing Solidarity Between \#BlackLivesMatter and Palestinian Activists" and the U.S. Campaign for Palestinian Rights voicing support for Black-Palestinian solidarity in 2014 indicates the growing support and sympathy for Palestinian aims, potentially sparked in part by the violence and inadequately-addressed racism that flourished under the Trump administration. 
Joe Biden's administration in part has restored funding toward Palestine, recommitting to UNRWA aid and reneging the Trump administration's promises to cut off all funding to Palestine. However, the administration has done little to engage on promises to facilitate a two-state solution, and has maintained a level of commitment to providing military funding and aid to Israel at an increasing rate. Facing pressure from both the left for not taking a more critical stance on Israel and the right for not "standing unequivocally" with Israel, according to Mike Pompeo (Washington Post) amid increasing Palestinian civilian casualties and escalating violence as of May 2021, Biden's failure to take a harder line against Israel in the interest of preserving a Palestinian state is reflective of decades of effort to bind the American-Israeli narrative together, focusing instead on commitment to history and values rather than the current state of affairs. As I've established, these policy stances are also not indicative or reflective of trends in public opinion, which have steadily diverged away from Israeli hegemony and instead toward a negotiated two-state solution. To fully understand how the influence of America's vested interest in Israel on the American public has faded, yet still fails to be represented in any policy or significant change in funding or operations, the nature of this shift and its relative impact has to be explored further.

\section{Changing tides: Public support for a two-state solution}

New Gallup poll data from February 2021 shows American opinion toward a two-state solution has barely wavered from the previous February 2020 data, where 55\% supported the establishment of an independent Palestinian state. Now in 2021, 52\% of Americans support the establishment of an independent Palestininan state, with 34\% of the total (compared to the previous year's 27\%) wanting the pressure increased on Israel. According to Gallup, this is the 
highest demand for increased pressure on Israel since 2007. These are slim margins, and the numbers indicate a higher level of sympathy and support for Israeli government than with the Palestinian Authority, as expected given previous years' trends, along with the United States' vested partnership with Israel and the aforementioned creation of narrative parallels that establish historical connection between the two states. However, this change is still significant, representing the first time in eight years public support has been behind an independent Palestinian state, with support seemingly paradoxically increasing under the Trump administration and decreasing under the Biden administration, according to Gallup polls, trends which I'll examine later to determine how they reflect changing tides in the American left and right, respectively.

In examining this change in public opinion, it's also important to mention the way Gallup framed the polling question, which was as follows: "Do you favor or oppose the establishment of an independent Palestinian state on the West Bank and the Gaza Strip?" While this partially addresses the question of land reclamation, it does not address the territory of East Jerusalem or other holy sites, and is specifically based around the land claimed by Israel after the 1967 war, rather than being based on the bounds of the territory as established by the 1947 partition plan or any subsequent divisions of land. However, these changes indicate despite the narrative indicating the public's ties should be with Israel, these views are not stagnant. Increasing sympathies for the Palestinian Authority (Gallup), as well as the demand for increased pressure on Israel to compromise toward a two-state solution, shows definitive public support for an independent Palestinian state.

An analysis of the literature in the field suggests scholars are pragmatic but divided about these poll results in terms of the future of U.S.-Israeli foreign policy, given the established 
political history and joint narrative of the two states, as illustrated in earlier sections. Scholars in the field address the U.S. failure to maneuver toward implementing a two-state solution given this new polling data in a few varying ways. For example, James Stimson in Tides of Consent: How Public Opinion Shapes American Politics argues change only occurs when the "threshold of normal public inattention is crossed" $(1,23)$. Public opinion is the biggest driver of change, and thus policy and political platforms are formed by it. This answers the question of why politicians aren't immediately mirroring changes in opinions, but it doesn't explain the vast inequity in two-state solution platforms as reflected by modern politicians. By Stimson's argument, this threshold has been crossed, as the boundary from less than half to more than half is significant enough to draw nationwide attention, as seen in Gallup reports and the amount of research published on the developing trend. Similarly, as I'll address later, the issue has been brought to national attention by tying it to the Black Lives Matter movement, arguably driving it through the threshold of public inattention despite lawmakers' staunchly pro-Israel votes (Rynhold, 55).

Lawrence Jacobs and Benjamin Page, on the other hand, pose an interesting addendum to why the U.S. has not changed foreign policy to reflect public opinion in "Who Influences U.S. Foreign Policy?", arguing public opinion has little to no influence on foreign policy or policymaker's behavior. In their study of the comparative influence of public opinion as compared to other factors, such as interest groups and lobbies, they found that the percentage of policy makers preferring a specific policy was "most strongly correlated with the percentage preferring the same policy among respondents from the media, business, foreign policy organizations," followed closely by think tanks, educators and religious leaders, etc (Jacobs and Page 113). The general public was dead last. This helps explain the disparity between public 
opinion and politician's actions, especially as Jacobs and Page also found evidence suggesting that public opinion of foreign policy preferences had little or no significant effect on government officials (Jacobs and Page 121). However, despite the overarching influence of business leaders in the U.S. and the seeming lack of influence coming from public opinion, Jacobs and Page add the general public can have an effect on foreign policy — but only under certain conditions. The authors give the example of democratic opposition to pro-Israeli government legislation, when it occurs, dampening or reversing momentum for the passage of laws in Congress. This argument accepted, the reason we have not seen overwhelming changes in foreign policy for the establishment of an independent Palestinian state is because those conditions — being a "highly salient questions of war and peace" and specific rhetorical packaging parallel to media interest (Jacobs and Page 118) — have not yet been met. Were all those conditions met concurrently, public opinion would have a greater effect. They give the example of effects on House members and economic policy as things influenced by public opinion outside these bounds, which we see align with the rise of new House members with vocal pro-Palestine positions in the last few years (Sprusansky, 18).

Mark Warren and Darren Castiglioni also highlight an important facet of the scholarly debate in "Representation Revisited," arguing there has been a recent change in democratic representation of increasingly powerful transnational players in "decision-making arenas" (5) that expand beyond nation-based democratic representation. This expansion is responsible for the gap between constituent demands and representatives' actions. Because of the newfound prominence of what the authors call "supra-national" forces, democratic representation as a relationship between constituent and politician has to be approached differently, belaying the idea of public opinion influencing politicians and instead incorporating it into this new structure. 
Israel is becoming an increasingly powerful transnational player under Warren and Castiglio's defined structure, and those decision-making arenas are limited to the executive branch, where everything from policy initiatives to political party verbiage on the subject stem from. This is accepting the theory of a joint narrative powering, but it's worthwhile to mention notable scholars in the field, such as John Mearsheimer and Stephen Walt in The Israel Lobby and U.S. Foreign Policy, attribute the unchanging American political commitment to Israel to the actions of the Israel Lobby, a conglomeration of pro-Israel groups that influence U.S. foreign policy from the bottom-up.

Jacobs and Page also examine the Israel Lobby concept as being important to the academic field as a way of conceptualizing the power of pro-Israeli influences on politics, but argue it fails to address the interests of the United States in a way that combines both strategic interest, and as I would argue, underpinning ideology. Similarly, Warren and Castiglioni suggest navigating the new world dynamic created by increased military influence by giving groups such as the Israel Lobby access to formal structures to balance it out. However, this "legitimate and legal way for groups and constituents to represent their beliefs beyond representation" works solely if you are in favor of the increasing Israeli autonomy over West Bank territories, areas of Jerusalem, holy sites and more. This Lobby, according to Mearsheimer and Walt, consists of pro-Israel groups shifting U.S. foreign policy in a pro-Israel direction. One in favor of a U.S.-negotiated two-state solution — with the critical end goal of an independent, autonomous Palestinian state — would not be able to pitch in their contributions to a collective group. According to Gallup polling data, Americans are still pro-Israel by wide margins, but that group does not take into account the parallel goal many Americans hold of facilitating that said 
two-state solution. The Israel Lobby, then, is legal and legitimate but nonrepresentative, and thus does not work as an effective method to translate constituent demands into praxis or policy.

Alternatively, Haim Malka in Crossroads: the Future of the U.S.-Israel Strategic Partnership illustrates another strategy of approach for explaining why public opinion has shifted, but policy has not. He argues that "profound demographic, social, and political transformations are reshaping the U.S.-Israeli relationship" (3). The rapidly changing environments, from a polarized right-leaning Israeli government to the impact of a four-year presidency under a right-leaning American government, have created a polarized environment where compromise is less likely and concessions are viewed as defeats. Malka further argues that the strife between the Obama and Netanyahu administrations created a deep divide that bled into public opinion of the U.S.-Iraeli partnership, actually increasing pro-Israel groups' criticism of U.S. actions and furthering a deepened support between the two states as part of a public maneuver to increase public support of the administration (18). This is likely partially the cause of the significant dip in support of an independent Palestinian state between the years 2008-2017. However, given the transition to a government significantly more sympathetic to Israel in 2016, what explains the constant increase in support for a two-state solution with an independent Palestine from 2017-2020, a much shorter timespan?

As I previously argued, this may be due to an increase in Republican support specifically for a U.S.-negotiated two-state solution - a group that has remained stalwartly in favor of Israel and the Israeli government for the past six decades (Gallup 2020). In 2016, the Republican National Convention voted unanimously to drop verbiage supporting a two-state solution from its platform (Kornbluh 2016), and only 12\% supported increasing pressure on Israel to resolve the Israeli-Palestinian crisis (Gallup 2021). However, in 2021, 17\% supported increasing 
pressure (the highest since 2008), and 44\% favored statehood, as opposed to $25 \%$ in 2017

(Gallup 2020). This relatively small but significant difference in support may have come from the Trump administration's public-facing front of facilitating a two-state solution, since as mentioned before, the Middle East Peace Plan and further moves by the Trump administration worked in a complex way, allowing for greater sympathies toward a two-state solution in the consistently pro-Israel republican sector. This combined with the steep drop in Democratic support for Israel from 2014-2020 combined may help explain the shift in public support for a two-state solution.

\section{ii. The Two-Party Split}

Jonathan Rynhold in "Democrats' attitudes toward the Israeli-Palestinian Conflict" does not draw the distinction between party lines, but rather associates the trend of liberal Democrats' growing support for an independent Palestine to a variety of extra-party factors. First, changes in Israeli domestic policy and the Netanyahu administration have sparked sympathy for Palestine and the reverse for Israel, as Netanyahu's right-leaning policies and continued push for settlements drive Israel further from an equitable two-state solution (53-54). Second, Rynhold attributes this burst of sympathy as part of the growing Black Lives Matter movement, in which a narrative was created tying racial discrimination in America to Palestinians and the Palestinian independence movement (55).

The complexities of party identity and support of a two-state solution are reflected in Asher Arian and Michael Shamir's “The Primarily Political Functions of the Left-Right Continuum," where they argue party spaces and ideological spaces function separately from each other. Labels of "left" and "right" do not predetermine ideology, which is why it is not useful 
from a political science perspective to establish the "Israel issue" on party boundaries (140). This explains the complexity behind shifting tides for a two-state solution due to the actions of a president operating outside the typical two-party boundary. This also helps to explain why American Christian support along both party lines has remained consistently supportive of Israel and to a lesser degree, a one-state solution with Israeli supremacy. According to Malka, "the constituencies that traditionally drove the relationships in both countries are increasingly divided and shrinking, while groups with very different outlooks and aspirations are coming to the forefront" (18). Interestingly, Malka implies that "shared values are no longer a given," indicating a novel divide. However, it seems for the moment, shared values are still very much in place. In a 2020 vote on the official Democratic Party platform prior to the 2020 elections, Senator Bernie Sanders proposed an amendment to add more conditions to giving military aid to Israel, as well as adding stronger language on ending the illegal occupation of the West Bank and "Israel's military rule over the Palestinians" (The Nation). The amendment was overwhelmingly rejected, 117 voting against and 34 voting in favor.

According to the same Gallup polling data from 2020, support among Democrats for Palestinian statehood reached $70 \%$. As Rynhold points out, this trend is related to a majority of Democrats supporting punitive action against Israel over new settlements in the West bank (56). This is clearly not reflected in Democratic congresspersons' policy platforms or voting patterns if the same disparate gap between public opinion and policy platforms is represented not only in the elected officials responsible for determining party ideology, but also in the party itself. Public opinion data taken from Democrats shows those who identify with the party are in favor of establishing an independent Palestinian state. According to Gallup polling data from 2021, nearly two-thirds of Democrats view Israel favorably, but also favor Palestinian statehood. Less than 
half sympathize more with Israel in regards to the dispute, and a majority want the U.S. to put more pressure on Israel. However, the official Democratic party platform does not reflect facilitating a two-state solution, let alone expresses a desire to see an independent Palestinian state realized. The official 2020 platform states "Our commitment to Israel's security, its qualitative military edge, its right to defend itself, and the 2016 Memorandum of Understanding is ironclad" (91), the referenced MOU allotting $\$ 3.8$ billion per year in military aid to Israel until FY2028 - \$8 billion more than the previous 10-year MOU agreement. The platform also states "We will help to bring to an end a conflict that has brought so much pain to so many. We support a negotiated two-state solution that ensures Israel's future as a Jewish and democratic state with recognized borders and upholds the right of Palestinians to live in freedom and security with a viable state of their own" (91). It does not equate "viable" with independent, nor is an independent Palestinian state not under the jurisdiction of the Israeli government mentioned. It also states "we oppose any effort to unfairly single out or delegitimize Israel, including at the United Nations or through the Boycott, Divestment, and Sanctions Movement” (91). The language is reminiscent of the commitment to being the "political shield"that Heller describes against international criticism (2).

The official Republican platform from 2016, which stands as the most current after the RNC voted in 2020 not to adopt a new platform until 2024, also states "unequivocal support" for Israel. It states Israel shares the United States" "most essential values," and therefore "support for Israel is an expression of Americanism" (47). The verbiage within the platform explicitly draws a line between the U.S. and Israel, both as countries born from the "aspiration for freedom," which stand out as "beacon[s] of democracy and humanity" (47). The platform only mentions Palestine once, to emphasize that the U.S. should halt its funding to the U.N., explicitly because 
the U.N. "grants Palestinians membership as a state" (22). Status as a non-member observer state, which the platform does not mention, goes against both archaic American laws, as well as the principle of protecting the U.S.-Iraeli relationship.

\section{Conclusion}

Not only is it relevant to all Americans as constituents to address the inherent contradictions in U.S. foreign policy with the projected goal of a two-state goal, it is also time-sensitive: authors from Princeton in 2012 argued although a two-state solution is still viable, growing obstacles may become insurmountable if current trends continue. They list a variety of time-sensitive concerns, such as Israel's expansion of settlements, the Israeli government creeping increasingly toward authoritarianism, and the disintegration of the Palestinian Authority as a competent legal and administrative body. Failures to reach a two-state solution and put in place measures to give Palestinians legal jurisdiction, have also created disillusionment and dissatisfaction, which the authors argue could contribute toward anti-two-state-solution sentiments. These conclusions are no less pressing nine years later — in fact, new crises are afoot, spurred by rigid American support of Israel as both governments become increasingly polarized.

Since 2012, the international community has also taken no significant steps towards facilitating a two state solution, despite increasing support for a negotiated solution. In 2018, members of the United Nation pushed for Israeli-Palestinian talks, arguing the international community must take "urgent action to end the suffering of the Palestinian people" (UN General Assembly 2018). Greater pushes in the international community to accord and recognize Palestine as an independent state. If, like Stimson argues, a "threshold of normal inattention" has 
been crossed regarding the Israel-Palestine conflict for Americans, then we should see a reflected effort by the state to support a two-state solution and broker peace in the region (23). This is unlikely, due to the parallel narrative the U.S. government has created between Israel and America, used to justify America's entrenched investment in Israel as a mitigating state to other foreign powers in the Middle East, as well as research indicating public opinion does not hold as much of a sway in influencing policies as other factors, such as industry and interest groups. However, despite the mitigating factors of growing polarization on both sides, this new divide is the result of overcoming 60 years of deeply ingrained popular opinion, and is an indicator of the possible change to come.

In order to effectively see public opinion realized into foreign policy, the government must change drastically to represent constituents' wishes, focusing on increased support for an independent Palestine paired with foreign policy objectives that strip power from Israel as a consequence for failing to facilitate this goal. Future research might focus on how these changing attitudes in Congressional party members influence the general public, or why committees reluctant to change have the power to defeat bills reflective of a changing public environment. However, for now, public norms are slowly but conclusively changing with the rise in solidarity for Palestinians paired with the Black Lives Matter movement, as well as warming attitudes toward an independent state and new members of Congress pushing the boundaries of “acceptable" platforms toward Israel and the negotiation of a two-state solution, indicating a hopeful future with a better chance of change, despite the prescient influence of the American-Israeli narrative. 


\section{Bibliography}

Arian, Asher, and Michal Shamir. "The Primarily Political Functions of the Left-Right Continuum.” Comparative Politics, vol. 15, no. 2, 1983, pp. 139-158. JSTOR, www.jstor.org/stable/421673. Accessed 29 Nov. 2020.

Byron, Jim. “The Quotable Richard Nixon.” Richard Nixon Foundation, 19 Dec. 2019, www.nixonfoundation.org/2011/04/the-quotable-richard-nixon/.

Cavari, Amnon. "Six Decades of Public Affection," Robert O. Freedman ed., Israel and the United States. Boulder: Westview Press: 2012, pp. 100-123.

https://doi.org/10.4324/9780429499579

Farrington, et al. "Exploring Alternatives to the Two-State Solution In the Palestinian-Israeli Conflict." Woodrow Wilson School Graduate Policy Workshop, Dec. 2012, spia.princeton.edu/sites/default/files/content/other/591d-Workshop-FinalReport-Israel-Main.pdf.

Gharib, Ali. "How Bernie Sanders Lost the Platform Fight Over Israel.” The Nation, 28 July 2016, www.thenation.com/article/archive/how-bernie-sanders-lost-the-platform-fight-over-israel/.

Heller, Mark A. "The United States and Israel: The Risk of Growing Apart.” SWP, German Institute for International and Security Affairs, Dec. 2019, www.swp-berlin.org/10.18449/2019C50/.

Jacobs , Lawrence R, and Benjamin I Page. "Who Influences U.S. Foreign Policy? .” American Political Science Review, vol. 99, no. 1, 2005, www.jstor.org/stable/30038922? casa token=qnt-OCkZsDcAAAAA\%3ACWhGnDJiDaHYyywg my4Ik8MIeDqixzDUJdt3EprHpeMnxW1Ro2mRUOnML1UremGsgma85iZYff_OIWBYADZae pk1e6FS2b511KaPpTuObHXVDsiY11c\&seq=1\#metadata info tab contents.

Kaplan, Amy. Our American Israel: the Story of an Entangled Alliance. Harvard University Press, 2018.

Kertzer, Joshua D., and Thomas Zeitzoff. "A Bottom-Up Theory of Public Opinion about Foreign Policy." American Journal of Political Science, vol. 61, no. 3, 2017, pp. 543-558., doi:10.1111/ajps.12314.https://onlinelibrary.wiley.com/doi/abs/10.1111/ajps.12314?campaign=w olearlyview

Khalidi, Rashid. Iron Cage: The Story of the Palestinian Struggle for Statehood, Beacon Press, 2006. ProQuest Ebook Central, http://ebookcentral.proquest.com/lib/psu/detail.action?docID=3117993. 
Landler, Mark. “Trump Recognizes Jerusalem as Israel's Capital and Orders U.S. Embassy to Move." The New York Times, 6 Dec. 2017, www.nytimes.com/2017/12/06/world/middleeast/trump-jerusalem-israel-capital.html.

Levendusky, Matthew, and Morris, Fiorina. "Disconnected: The Political Class Versus the People." in Red and Blue Nation? ed. Pietro S. Nivola and David W. Brady, Vol. 1. (Washington, DC: Brookings Institution Press 2006); Nate Silver, “As Swing Districts Dwindle, Can a Divided House Stand?," FiveThirtyEight Blog, December 27, 2012.

Malka, Haim. Crossroads: the Future of the U.S.-Israel Strategic Partnership. Center for Strategic and International Studies, 2011, csis-website-prod.s3.amazonaws.com/s3fs-public/legacy_files/files/publication/110908_Malka CrossroadsUSIsrael_Web.pdf.

Marrar, Khalil. The Arab Lobby and US Foreign Policy: The Two-State Solution, 2008, The Arab Lobby and US Foreign Policy: The Two-State Solution. 1-269. 10.4324/9780203887394.

Mearsheimer, John J., and Stephen M. Walt. The Israel Lobby and U.S. Foreign Policy. Betascript, 2010, www.academia.edu/9031239/The Israel_Lobby and USS Foreign_Policy John_Mearsheimer Stephen Walt.

Nauert, Heather. “On U.S. Assistance to UNRWA," State Department, Washington D.C., 31 Aug. 2018.

Pamuk, Humeyra, and Arshad Mohammed. "Pompeo Says Annexation of West Bank Is Israeli Decision to Make.” Reuters, 22 Apr. 2020, www.reuters.com/article/uk-israel-politics-pompeo-idUKKCN2242HY.

Pitkin, Hanna Fenichel. The Concept of Representation. Univ. of Calif. Press, 1967.https://books.google.com/books?id=AgUVWLswTNEC\&printsec=frontcover\&source=gbs ge summary $\mathrm{r} \& \mathrm{cad}=0 \# \mathrm{v}=$ onepage $\& \mathrm{q} \& \mathrm{f}=$ true

RNC Communications. "The 2016 Republican Party Platform.” GOP, 18 July 2016, www.gop.com/the-2016-republican-party-platform/.

Rynhold, Jonathan. "Democrats' attitudes toward the Israeli-Palestinian Conflict." Middle East Policy, vol. 27, no. 4, 2021, pp. 46-61. https://doi.org/10.1111/mepo.12526

Saad, Lydia. “Americans, but Not Liberal Democrats, Mostly Pro-Israel.” Gallup, 6 Mar. 2019, https://news.gallup.com/poll/247376/americans-not-liberal-democrats-mostly-pro-israel.aspx 
Saad, Lydia. “Americans Remain Staunchly in Israel's Corner.” Gallup, 13 Mar. 2018, https://news.gallup.com/poll/229199/americans-remain-staunchly-israel-corner.aspx

Saad, Lydia. "Americans Still Favor Israel While Warming to Palestinians." Gallup, 19 Mar. 2021, news.gallup.com/pol1/340331/americans-favor-israel-warming-palestinians.aspx.

Saad, Lydia. "Majority in US Again Support Palestinian Statehood," Gallup, 23 Mar. 2020, news.gallup.com/pol1/293114/majority-again-support-palestinian-statehood.aspx.

Scham, Paul \& Pogrund, Benjamin \& Ghanem, Asad. "Introduction to Shared Narratives-A Palestinian-Israeli Dialogue.” Israel Studies, 2013, 18. 1-10. 10.2979/israelstudies.18.2.1.

Schiff, Benjamin N. "Defunding aid for Palestinian refugees is not a road to peace." The Hill, 12 Sept. 2018, https://thehill.com/opinion/international/406306-defunding-aid-for-palestinian-refugees-is-not-aroad-to-peace

Sharp, Jeremy Maxwell. Congressional Research Service, United States Congress, CRS Reports, 16 Nov. 2020. https://crsreports.congress.gov/product/pdf/RL/RL33222

Stimson, James A. Tides of Consent: How Public Opinion Shapes American Politics. Cambridge University Press, 2015, books.google.com/books?hl=en\&lr=\&id=f6JrCgAAQBAJ\&oi=fnd\&pg=PR8\&ots=juyb9K4b4Z \&sig=1-IVuFp7QiT1jMZWZ4sUf4pKcls\#v=onepage\&q\&f=false, Accessed 2020.

Tharoor, Ishaan. "The Growing Solidarity Between \#BlackLivesMatter and Palestinian Activists." The Washington Post, 15 Oct. 2015,

www.washingtonpost.com/news/worldviews/wp/2015/10/15/the-growing-solidarity-between-bla cklivesmatter-and-palestinian-activists/.

Tharoor, Ishaan. "The U.S. conversation on Israel is changing, no matter Biden's stance." The Washington Post, 16 May 2021, https://www.washingtonpost.com/world/2021/05/17/biden-israel-palestinians-change/ .

The 2020 Platform Committee. The 2020 Democratic Platform. Democratic National Convention, 29 Aug. 2020, democrats.org/where-we-stand/party-platform/.

United Nations General Assembly. "As General Assembly Debates Question of Palestine, Members Call for Swift Action to Jump-Start Israeli-Palestinian Talks, Realize Two-State Solution | Meetings Coverage and Press Releases." United Nations, 29 Nov. 2018, www.un.org/press/en/2018/ga12095.doc.htm. 
United States Congress, "Defense, Commerce, Justice, Science, Energy and Water Development, Financial Services and General Government, Labor, Health and Human Services, Education, Transportation, Housing, and Urban Development Appropriations Act, 2021." Congress, 2019. www.congress.gov/bill/116th-congress/house-bill/7617.

United States Congress, "Promoting Human Rights by Ending Israeli Military Detention of Palestinian Children Act." Congress, 2017. www.congress.gov/bill/115th-congress/house-bill/4391.

United States Congress, “ Promoting Human Rights for Palestinian Children Living Under Israeli Military Occupation Act.” Congress, 2019.

www.congress.gov/bill/116th-congress/house-bill/2407/all-actions-without-amendments.

Warren, Mark, and Darren Castiglio. "Representation Revisited." Democracy \& Society, vol. 2, no. 1, 2004.

https://citeseerx.ist.psu.edu/viewdoc/download?doi=10.1.1.472.5220\&rep $=$ rep1\&type $=p d f$

White House, Office of the Press Secretary. "FACT SHEET: Memorandum of Understanding Reached with Israel." National Archives and Records Administration, National Archives and Records Administration, 14 Sept. 2016, obamawhitehouse.archives.gov/the-press-office/2016/09/14/fact-sheet-memorandum-understandi ng-reached-israel

Zanotti, Jim. Congressional Research Service, United States Congress, CRS Reports, 18 Dec. 2018. https://fas.org/sgp/crs/mideast/RS22967.pdf.

Zunes, Stephen. "Why the U.S. Supports Israel." Institute for Policy Studies, 26 Feb. 2020, ips-dc.org/why_the_us_supports_israel/. 